\title{
EFEKTIVITAS BERBAGAI BIOAKTIVATOR TERHADAP PEMBENTUKAN KOMPOS DARI LIMBAH SAYUR DAN DAUN
}

\author{
Effectiveness of Variety Bio-Activator Against Formation of Compos \\ from Vegetable Waste and Leaves
}

\author{
Darmawati \\ Fakultas Keguruan dan Ilmu Pendidikan (FKIP), Universitas Riau \\ Kampus Binawidya Km. 12,5 Pekanbaru. 28293. Riau. Telp.0761 63273 Ext.106/085313414657
}

[Diterima Maret 2015, Disetujui Juni 2015]

\begin{abstract}
This research aims to determine the effectiveness of various bio-activators on the composting of vegetable and leave waste. This research was carried out from April to November 2014. The type of research is an experiment by using a Comletely random, consisting of 4 treatments and 3 replications. Research procedure consisted of four stages, namely preparation of tools and materials, the implementation phase of composting, observation of the composting process, and the completion stage. The observed parameters were the texture, length of composting, $\mathrm{C} / \mathrm{N}$ ratio of compost, temperature, humidity, and $\mathrm{pH}$. Data were analyzed quantitatively using the $\mathrm{C} / \mathrm{N}$ ratio and the length of time the composting and analysis of variance (ANOVA) and also DMRt test at significant level of $5 \%$, while qualitative analysis was used for the compost texture, temperature, humidity, and $\mathrm{pH}$. The results showed the effectiveness of bio-activator EM4, Acticomp, and Orgadec hade an effect on the composting of vegetable waste and leaves. Acticomp bio-activator was the best bio-activator to produce compost from vegetable waste and leaves.
\end{abstract}

Keywords: Bio-activator, Effectiveness, Compost, Waste

\begin{abstract}
ABSTRAK
Penelitian ini bertujuan untuk mengetahui efektifitas berbagai bioaktivator terhadap pembentukan kompos dari limbah sayur dan daun. Penelitian ini dilaksanakan pada bulan April sampai November 2014. Jenis penelitian adalah eksperimen dengan RAL yang terdiri dari 4 perlakuan dan 3 ulangan. Prosedur penelitian terdiri atas 4 tahap, yaitu penyiapan alat dan bahan, pelaksanaan tahap pengomposan, pengamatan proses pengomposan dan tahap penyelesaian. Parameter pada penelitian ini adalah tekstur, lama waktu pengomposan, rasio $\mathrm{C} / \mathrm{N}$ kompos, suhu, kelembaban dan $\mathrm{pH}$. Data yang diperoleh dianalisis secara kuantitatif menggunakan rasio $\mathrm{C} / \mathrm{N}$ dan lama waktu pengomposan dan sidik ragam Anava dan bila berbeda nyata dilanjutkan dengan uji DMRT pada taraf $\propto 5 \%$, sedangkan tekstur kompos, suhu, kelembaban dan $\mathrm{pH}$ dianalisis secara kualitatif. Hasil penelitian menunjukkan efektivitas bioaktivator EM-4, Acticomp dan Orgadec memberikan pengaruh terhadap pembuatan kompos dari limbah sayur dan daun. Bio-aktivator Acticomp merupakan bio-aktivator terbaik dalam menghasilkan kompos dari limbah sayur dan daun.
\end{abstract}

Kata Kunci: Bio-aktivator, Efektifitas, Kompos, Limbah

\section{PENDAHULUAN}

Limbah adalah bahan yang terbuang atau dibuang dari suatu aktivitas manusia atau proses alami yang belum mempunyai nilai ekonomi, tetapi justru memiliki dampak negatif terhadap lingkungan. Dampak negatif yang dimaksud adalah proses pembuangan dan pembersihannya memerlukan biaya serta efeknya dapat mencemari lingkungan. Limbah dapat berasal dari aktifitas manusia seperti limbah pertanian, diantaranya: jerami padi, tonggol jagung, garbage berupa sisa budidaya sayur mayur dan limbah yang tidak berasal dari aktifitas manusia seperti dedaunan. Limbah tersebut digolongkan kedalam limbah organik. Limbah organik dapat dengan mudah terurai menjadi kompos. Oleh sebab itu, pengomposan merupakan alternatif penanganan yang sesuai untuk mengurangi 
dampak negatif diatas, selain itu kompos juga memberi manfaat lain sebagai pupuk pada tumbuhan.

Pengomposan adalah proses dimana bahan organik mengalami penguraian secara biologis, khususnya oleh mikroba-mikroba yang memanfaatkan bahan organik sebagai sumber energi. Pengomposan dapat mengawetkan kelebihan unsur yang terkandung di dalam suatu limbah, seperti unsur Nitrogen $(\mathrm{N})$, Phospor $(\mathrm{P})$ dan Kalium (K) (Isroi, 2008). Pengomposan dapat terjadi secara alami maupun dengan penambahan bioaktivator. Pengomosan secara alami membutuhkan waktu yang cukup lama berkisar 6 bulan tetapi dengan penambahan bioaktivator yang dipasarkan, pengomposan dapat berlangsung selama 2-3 minggu. Berbagai macam bioaktivator yang digunakan adalah EM-4, Orgadec dan Acticomp. Masing-masing bioaktivator mempunyai kelebihan ataupun kekurangannya.

Effective Microorganism-4 (EM-4) adalah kultur campuran mikroorganisme yang bermanfaat seperti bakteri fotosintesis, bakteri asam laktat, ragi dan actinomycetes yang mempunyai peranan penting dalam proses perombakan bahan organik, menghilangkan bau busuk limbah organik, mempercepat penguraian limbah organik serta pengomposan berbagai macam limbah organik (Anif dan Astuti, 2008). Acticomp adalah produk BPBPI (Balai Penelitian Bioteknologi Perkebunan Indonesia) yang diformulasikan sebagai pendegradasi lignin dan selulosa tinggi yang diperkaya dengan mikroba Trichoderma harzianum (perangsang pertumbuhan tanaman), Aspergillus $s p$ (pelarut phospor) dan PGR (Plant Growth Promoting Rhizobacteria). Mikroba ini bekerja aktif pada suhu tinggi (termofilik) (BPBPI, 2009). Orgadec (Organic Decomposer) merupakan bioaktivator pengomposan dengan bahan mikroba asli Indonesia yang diproduksi LRPI (Lembaga Riset Perkebunan Indonesia). Orgadec berbahan aktif Trichoderma pseudokoningii dan Cytophaga sp memiliki kemampuan menghancurkan bahan organik mentah dalam waktu relatif singkat dan bersifat antagonis terhadap beberapa penyakit akar (BPTP, 2007). Kedua mikroba tersebut memiliki kemampuan yang tinggi dalam menghasilkan enzim penghancur lignin dan selulosa secara bersamaan. Dari ketiga bioaktivator ini belum diketahui manakah yang lebih efektif untuk menguraikan limbah sayur dan daun untuk menghasilkan kompos.

Berdasarkan latar belakang yang telah dikemukakan di atas, penelitian ini bertujuan untuk mengetahui efektivitas berbagai bioaktivator terhadap pembentukan kompos dari limbah sayur dan daun.

\section{METODE PENELITIAN}

Penelitian ini dilaksanakan di Laboratorium Alam Program Studi Pendidikan Biologi FKIP (pelaksanaan tahap pembuatan kompos) dan Laboratorium Program Studi Kimia FMIPA (pelaksanaan analisis unsur hara $\mathrm{C}$ dan $\mathrm{N}$ ) Universitas Riau, mulai dari bulan April sampai November 2014. Alat yang digunakan dalam pelaksanaan penelitian ini antara lain: baskom plastik diameter $16 \mathrm{~cm}$ sebanyak 12 buah, cangkul, soil tester, termometer, timbangan, parang, pengaduk, terpal, tali raffia, sarung tangan karet, kertas label, spidol permanen dan lakban bening. Bahan yang digunakan adalah limbah sayur dan daun, pupuk kandang, Orgadec, EM-4, Acticomp, gula merah serta air secukupnya.

Penelitian ini menggunakan Rancangan Acak Lengkap (RAL) yang terdiri dari 4 perlakuan dan 3 ulangan, yaitu:

$\mathrm{B}_{0}=1 \mathrm{~kg}$ limbah sayur $+1 \mathrm{~kg}$ daun + pupuk kandang $1 \mathrm{~kg}$

$\mathrm{B}_{1}=15 \mathrm{~g} \mathrm{EM}-4+1 \mathrm{~kg}$ limbah sayur $+1 \mathrm{~kg}$ daun + pupuk kandang $1 \mathrm{~kg}$

$\mathrm{B}_{2}=15 \mathrm{~g}$ Orgadec $+1 \mathrm{~kg}$ limbah sayur $+1 \mathrm{~kg}$ daun + pupuk kandang $1 \mathrm{~kg}$

$\mathrm{B}_{3}=15 \mathrm{~g}$ Acticomp $+1 \mathrm{~kg}$ limbah sayur $+1 \mathrm{~kg}$ daun + pupuk kandang $1 \mathrm{~kg}$

Prosedur Penelitian terdiri dari penyiapan alat dan bahan yang akan digunakan, pelaksanaan tahap pengomposan, pengamatan proses pengomposan dan tahap penyelesaian dengan parameter penelitian, antara lain: tekstur, lama waktu pengomposan, ratio $\mathrm{C} / \mathrm{N}$, dan parameter pendukung, seperti: suhu, kelembaban dan $\mathrm{pH}$.

1. Tekstur

Parameter tekstur akan dilakukan dengan uji organoleptik menggunakan indra peraba dan penglihatan pada setiap perlakuan di akhir pengamatan.

2. Lama waktu pengomposan

Untuk penentuan lama waktu pengomposan dinilai dari penyusutan berat kompos yang 
telah mencapai $60 \%$ (Nurullita dan Budiyono, 2012):

$\%$ penyusutan $=$ $\frac{\text { bobot awal-bobot akhir }}{\text { bobot awal }} \times 100 \%$

\section{Rasio C/N}

Menganalisa kompos di laboratorium.

4. Parameter pendukung : suhu, kelembaban dan $\mathrm{pH}$

Data yang diperoleh kemudian dianalisis secara kuantitatif dan kualitatif. Analisis secara kuantitatif dilakukan terhadap rasio $\mathrm{C} / \mathrm{N}$ dan lama waktu pengomposan dengan menggunakan sidik ragam Anova dan bila berbeda nyata dilanjutkan dengan uji DMRT pada taraf $\propto 5 \%$ Sedangkan data, tekstur kompos, suhu, kelembaban dan $\mathrm{pH}$ dianalisis secara dianalisis secara kualitatif .

\section{HASIL DAN PEMBAHASAN}

\section{Tekstur Kompos}

Rerata tekstur kompos dari limbah sayur dan daun dapat dilihat pada Tabel 1. Hasil organoleptik menunjukkan bahwa dari keempat perlakuan tidak berpengaruh terhadap tekstur pada kompos karena baik kompos yang dihasilkan pada kontrol maupun kompos yang dihasilkan dari perlakuan dengan penambahan ketiga bioaktivator tidak menunjukkan tekstur yang berbeda. Walaupun dari parameter tekstur tidak menunjukkan pengaruh penambahan bioaktivator, bukan berarti kompos yang dihasilkan tidak matang karena untuk mengetahui kematangan suatu kompos perlu memperhatikan ciri lainnya, terutama rasio $\mathrm{C} / \mathrm{N}$ kompos tersebut.

Hal ini sesuai dengan pernyataan Sudradjat dalam Pangestuti (2008) yang menyebutkan bahwa ciri visual dari kompos yang telah matang adalah tidak berbau, berwarna hitam, mudah hancur bila diremas tangan, tidak bercampur dengan insekta, cacing, ulat atau jamur di dalam kompos tersebut, namun secara laboratories nisbah $\mathrm{C} / \mathrm{N}$ di bawah 20 adalah indikasi bahwa proses composting telah berakhir. Untuk melihat tekstur kompos yang dihasilkan dapat dilihat pada Gambar 1.

Hasil pengomposan belum menunjukkan ciri kompos yang matang. Dari kompos yang dihasilkan menunjukkan kriteria sedang, yakni masih terdapat sebagian limbah yang masih menyerupai bentuk aslinya atau belum terurai secara merata seperti tanah. Hal ini disebabkan karena tingginya persentase kandungan lignin yang dimiliki oleh limbah daun berupa serasah daun yang telah kering, terutama berasal dari jenis Accasia sp.

Tabel 1. Hasil Organoleptik Rerata Tekstur Kompos Limbah Sayur dan Daun

\begin{tabular}{lc}
\hline \multicolumn{1}{c}{ Perlakuan } & $\begin{array}{c}\text { Rerata Tekstur } \\
\text { Kompos }\end{array}$ \\
\hline Kontrol & Sedang \\
EM-4 & Sedang \\
Orgadec & Sedang \\
Acticomp & Sedang \\
\hline
\end{tabular}

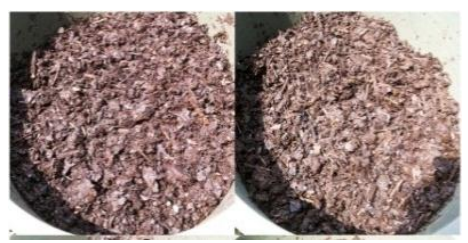

(a)

(b)

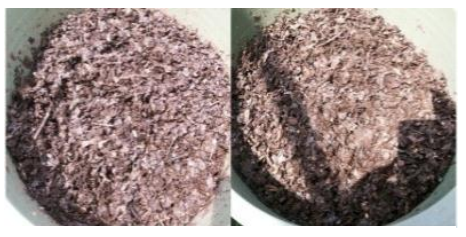

(c)

(d)

Keterangan: (a) Kontrol; (b) Perlakuan EM4; (c) Perlakuan Orgadec; dan (d) Perlakuan Acticomp

Gambar 1. Tekstur Kompos yang Dihasilkan Selama 8 Minggu

Kondisi tersebut sesuai dengan pernyataan Aprianis $d k k$ (2010) yang menyatakan bahwa kandungan lignin A. crassicarpa umur 3 tahun sebesar $27,22 \%$ sedangkan lignin $A$. crassicarpa umur 4 tahun sebesar $28,48 \%$. Besarnya kandungan lignin akan menghambat proses dekomposisi karena lignin merupakan senyawa yang komplek sehingga sulit terurai oleh mikroorganisme. Bila dibandingkan dengan kandungan lignin salah satu limbah yakni jerami padi sebesar $4-10 \%$, tentu saja kandungan lignin pada serasah daun dari limbah kebun tersebut dapat dikatakan cukup tinggi. Berbeda halnya jika kandungan bahan organik tersebut didominasi tinggi oleh karbohidrat ataupun selulosa. Selulosa secara normal mudah dicerna oleh bakteri, tetapi selulosa dari beberapa tanaman akan lebih sulit untuk didegradasikan bila dikombinasikan dengan lignin. Lignin adalah molekul kompleks yang memiliki bentuk rigid serta struktur berkayu 
dari tanaman dan bakteri hampir tidak dapat mencernanya (Meynel, dalam Syahputra, 2009).

\section{Lama Waktu Pengomposan}

Rerata nilai penyusutan berat kompos dapat dilihat pada Gambar 2. Pada Gambar 2, nilai penyusutan berat kompos terbesar pada perlakuan menggunakan bioaktivator Acticomp $(49,07 \%)$ dan terendah pada kontrol $(37,96 \%)$. Penyusutan berat kompos lebih tinggi pada ketiga perlakuan menggunakan bioaktivator dibandingkan dengan perlakuan kontrol. Hal tersebut disebabkan karena tidak ada penambahan bioaktivator pada perlakuan kontrol maka bahan baku limbah tersebut mengalami penyusutan berat yang sangat lambat, sedangkan pada perlakuan dengan menggunakan bioaktivator, mikroba seperti bakteri metanogenik aktif mengurai bahan organik menjadi $\mathrm{CO}_{2}, \mathrm{H}_{2} \mathrm{O}$, humus, unsur hara dan energi yang menyebabkan terjadinya kehilangan $\mathrm{CO}_{2}$ dan $\mathrm{H}_{2} \mathrm{O}$ yang cukup banyak selama proses pengomposan sehingga mengalami penyusutan pupuk kompos (Soepardi, dalam Astari, 2011).

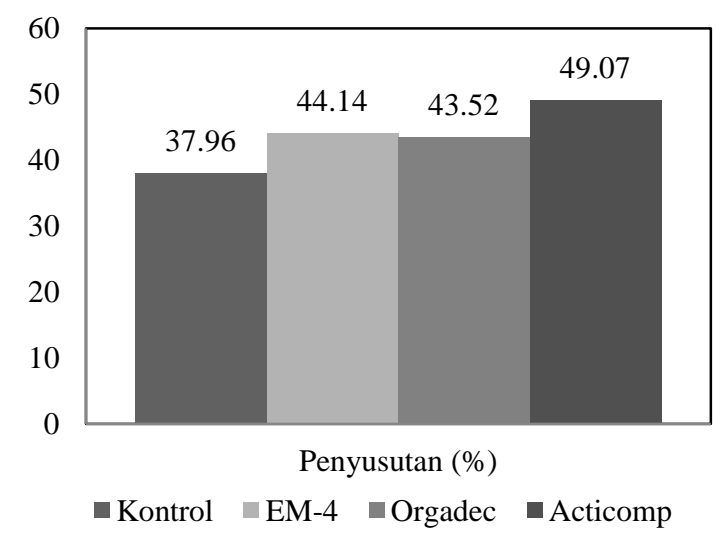

Gambar 2. Persentase Penyusutan Berat Kompos dari Limbah Sayur dan Daun

Jika dibandingkan antara ketiga perlakuan dengan menggunakan bioaktivator dapat diketahui bahwa perlakuan dengan menggunakan bioaktivator Acticomp menunjukkan penyusutan berat kompos yang lebih tinggi dibandingkan dengan bioaktivator lainnya Hal ini dikarenakan bioaktivator Acticomp memang dirancang khusus sebagai pendegradasi lignin dan selulosa yang tinggi serta dapat menurunkan rasio $\mathrm{C} / \mathrm{N}$ limbah organik yang tinggi dimana diperkaya dengan mikroba Trichoderma harzianum (perangsang pertumbuhan tanaman), Aspergillus sp (pelarut phospor) dan PGR
(Plant Growth Promoting Rhizobacteria) (BPBPI, 2009). Trichoderma memiliki potensi paling tinggi dalam perombakan lignoselulosa dibandingkan dengan jamur-jamur perombak lainnya. Hal ini disebabkan karena Tricoderma mampu menghasilkan enzim selulase yang mampu menghidrolisis bahan-bahan yang mengandung kadar lignoselulase yang tinggi (Makarim $d k k .$, 2007).

\section{Rasio C/N Kompos}

Rerata rasio $\mathrm{C} / \mathrm{N}$ kompos dapat dilihat pada Gambar 3. Pada Gambar 3, dapat perlakuan dengan menggunakan bioaktivator Acticomp menunjukkan rasio $\mathrm{C} / \mathrm{N}$ kompos yang paling rendah dibandingkan dengan bioaktivator lainnya pada. Hal ini dikarenakan bioaktivator Acticomp memang dirancang khusus sebagai pendegradasi lignin dan selulosa yang tinggi serta dapat menurunkan rasio $\mathrm{C} / \mathrm{N}$ limbah organik yang tinggi dimana diperkaya dengan mikroba Trichoderma harzianum (perangsang pertumbuhan tanaman), Aspergillus $s p$ (pelarut phospor) dan PGR (Plant Growth Promoting Rhizobacteria) (BPBPI, 2009). Trichoderma memiliki potensi paling tinggi dalam perombakan lignoselulosa dibandingkan dengan jamur-jamur perombak lainnya. Hal ini disebabkan karena Tricoderma mampu menghasilkan enzim selulase yang mampu menghidrolisis bahan-bahan yang mengandung kadar lignoselulase yang tinggi (Makarim $d k k$., 2007).

Menurut Sutanto (2002), rasio C/N berkenaan dengan indikasi intensitas proses dekomposisi bahan organik. Rasio $\mathrm{C} / \mathrm{N}$ yang cukup besar menunjukkan bahan sukar terdekomposisi, sedangkan rasio $\mathrm{C} / \mathrm{N}$ terlalu rendah menunjukkan bahan mudah terdekomposisi. Pada pengomposan jika rasio $\mathrm{C} / \mathrm{N}$ kompos tinggi maka kurang baik digunakan sebagai pupuk tanaman, sebaliknya jika rasio $\mathrm{C} / \mathrm{N}$ rendah maka penyerapan unsur hara dapat digunakan oleh tanaman karena bahan organik telah terurai oleh mikroba menjadi unsur-unsur yang dapat diserap oleh tanaman. Hal ini sesuai dengan pendapat Hanafiah (2005), menyatakan bahwa kompos dengan rasio $\mathrm{C} / \mathrm{N}$ tinggi tidak baik bagi tanaman dan pada saat pengaplikasian langsung ke tanaman akan terjadi kompetisi antara tanaman dengan mikroba dalam penyerapan unsur-unsur hara tersedia dalam tanah. Sebaliknya, jika rasio $\mathrm{C} / \mathrm{N}$ kompos rendah berarti unsur hara yang terikat pada kompos 
telah dilepaskan melalui proses mineralisasi sehingga dapat digunakan oleh tanaman. Maka perlakuan EM-4 memberikan rasio $\mathrm{C} / \mathrm{N}$ yang terendah, sehingga paling baik sebagai pupuk kompos bagi tanaman dibanding dengan perlakuan lainnya.

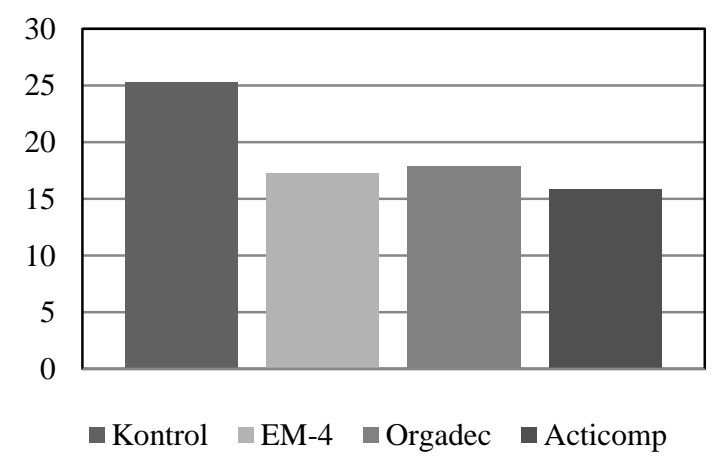

Gambar 3. Rasio C/N Kompos dari Limbah Sayur dan Daun

\section{Suhu}

Rerata suhu yang diukur selama 8 minggu dapat dilihat pada Gambar 4. Berdasarkan Gambar 4, menunjukkan bahwa setelah fase mesofilik, perlakuan EM-4 dan Orgadec berada di fase termofilik pada minggu pertama atau di hari ketujuh pengomposan untuk limbah jerami padi dan jagung serta perlakuan Acticomp untuk limbah jerami kebun dan pasar sebelum akhirnya mengalami penurunan suhu hingga stabil. Ini ditunjukkan dari perubahan suhu yang telah mencapai suhu puncak. Pada minggu pertama ini, mikroorganisme mesofilik digantikan oleh mikrorganisme termofilik yaitu bakteri termofilik, actinomycetes dan thermofilic fungi (Kastaman $d k k .$, 2006).

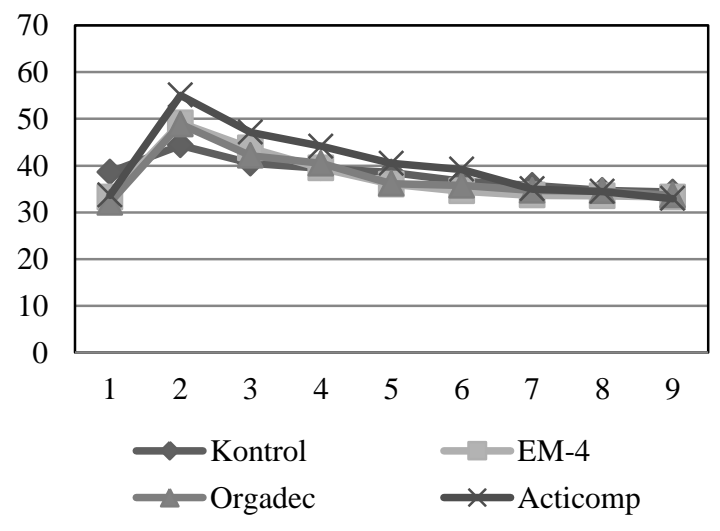

Gambar 4. Rerata Perubahan Suhu Timbunan Kompos Selama 8 Minggu
Bakteri termofilik yang tumbuh dakam waktu yang terbatas berfungsi untuk mengkonsumsi karbohidrat dan protein, sehingga bahan-bahan kompos dapat terurai dengan cepat. Fase termofilik adalah fase dengan temperatur $40-60^{\circ} \mathrm{C}$ dimana mikroorganisme dapat tumbuh dengan baik (Sutedjo $d k k$., 1991). Fase termofilik menandakan mikroorganisme mulai aktif mengurai bahan organik dan terjadinya proses penguraian mikroba yang menghasilkan panas pada kompos. Selama proses pengomposan berlangsung akan terjadi reaksi eksotermik sehingga timbul panas akibat pelepasan energi. Kenaikan temperatur dalam timbunan bahan organik menghasilkan suhu yang menguntungkan bagi mikroorganisme termofilik. Apabila suhu melebihi $65-70^{\circ} \mathrm{C}$, maka kegiatan mikroorganisme akan menurun karena kematian organisme akibat panas yang tinggi (Dalzell $d k k .$, 1987). Pada suhu ini juga, patogen, parasit dan benih gulma yang terbawa bahan akan mati (Wahyono $d k k$., 2011).

Setelah suhu puncak, keempat perlakuan menunjukkan penurunan suhu yang berkisar antara $32,9-34,33^{\circ} \mathrm{C}$ berarti bahwa suhu akhir dari keempat macam limbah tersebut tidak menunjukkan kisaran yang terlalu berbeda. Penurunan suhu ini dikarenakan aktivitas mikroba mulai menurun. Pada suhu ini merupakan tahap pendinginan atau fase pematangan dimana konsentrasi material organik pada kompos sudah menipis jumlahnya. Penurunan jumlah dan aktivitas mikroba menyebabkan suhu tidak meningkat lagi dan relatif stagnan (Wahyono $d k k$., 2011). Pada fase pematangan kompos ini juga terjadi pematangan kompos tingkat lanjut, yaitu pembentukan kompleks liat humus (Isroi, 2008). Suhu paling rendah ditunjukkan perlakuan Acticomp $\left(32,9^{\circ} \mathrm{C}\right.$ namun suhu inilah yang paling mendekati suhu air tanah $\left(30-32^{\circ} \mathrm{C}\right)$. Hal ini sesuai dengan kriteria kompos matang menurut SNI (2004). Suhu akhir paling tinggi di minggu kedelapan ditunjukkan oleh perlakuan kontrol $\left(34,33^{\circ} \mathrm{C}\right)$ dimana suhu ini masih kurang mendekati standar suhu kompos yang ditetapkan SNI.

\section{Kelembaban}

Rerata kelembaban kompos dapat dilihat pada Gambar 5. Pada Gambar 5, rerata persentase kelembaban kompos tertinggi di awal penelitian, terdapat pada kontrol sebesar $60,33 \%$ dimana limbah hanya ditambahkan 
kotoran sapi, sedangkan kadar air terendah di awal penelitian sebesar $58 \%$ terdapat pada kompos dengan pemberian bioaktivator Orgadec, namun rendahnya kelembaban kompos pada perlakuan ini tidak terlalu berbeda jauh dengan perlakuan lainnya. Kisaran kelembaban kompos tersebut masih dikatakan berada pada kondisi optimum dimana kondisi optimum kadar air tumpukan limbah padat dalam proses pengomposan sekitar 40-60\% (Wahyono $d k k$., 2011).

Untuk kelembaban kompos di akhir penelitian tidak menunjukkan perbedaan yang signifikan dimana berkisar antara 44,6749,33\%. Kelembaban ini mendekati nilai maksimal kelembaban kompos yang baik di SNI 19-7030-2004 sebesar 50\%. Pada kelembaban yang tinggi, aktivitas bakteri maksimum sebaliknya pada kelembaban rendah jamur akan lebih aktif (Hanafiah, 2005). Kelembaban berperan penting dalam proses dekomposisi (pengomposan) bahan baku kompos, karena berhubungan dengan aktivitas mikroorganisme. Kelembaban campuran bahan kompos yang rendah (kekurangan air) akan menghambat proses pengomposan dan akan menguapkan nitrogen ke udara. Namun, jika kelembabannya tinggi (kelebihan air), proses pertukaran udara (aerasi) dalam campuran bahan kompos akan terganggu.

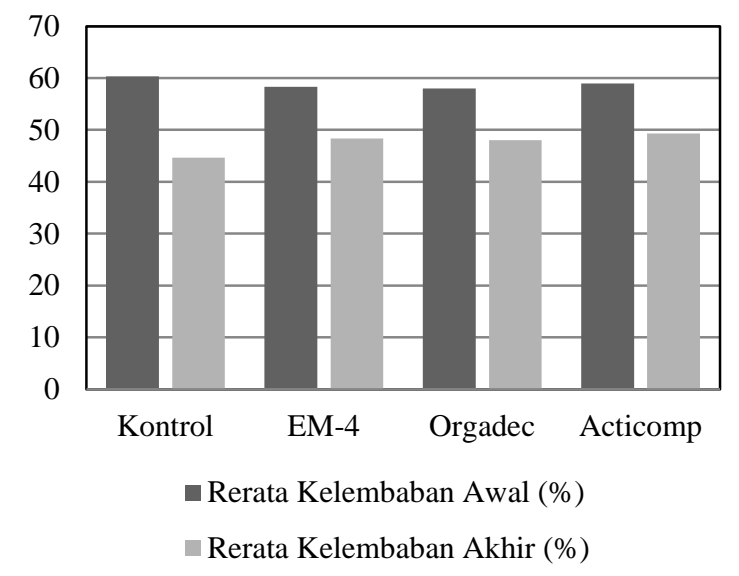

Gambar 5. Rerata Kelembaban Kompos di Awal dan Akhir Penelitian

Pori-pori udara yang ada dalam tumpukan bahan kompos akan diisi oleh air dan cenderung menimbulkan kondisi anaerobik (Manser, 2008).

\section{PH}

Hasil pengukuran $\mathrm{pH}$ menunjukkan perubahan ke arah kestabilan $\mathrm{pH}$ dari awal ke akhir penelitian. Standar kualitas kompos dari parameter $\mathrm{pH}$ menurut SNI yaitu minimum 6,80 dan maksimum 7,49. Untuk lebih rerata $\mathrm{PH}$ kompos dapat dilihat pada Gambar 6. Hasil penelitian menunjukkan bahwa $\mathrm{pH}$ dari keempat perlakuan mengalami peningkatan di akhir penelitian. Peningkatan nilai $\mathrm{pH}$ kompos disebabkan karena adanya aktivitas mikroorganisme dalam bioaktivator yang memberikan masukan ion $\mathrm{OH}^{-}$dari hasil proses dekomposisi bahan kompos. Menurut Buckman dan Brady (1982), bahwa hasil proses dekomposisi bahan organik oleh mikroorganisme menghasilkan ion $\mathrm{OH}^{-}$ sehingga menunjang peningkatan kebasaan yang selanjutnya meningkatkan nilai $\mathrm{pH}$ kompos tersebut.

Pengukuran $\mathrm{pH}$ kompos di awal penelitian menunjukkan nilai terendah pada perlakuan kontrol $(6,3)$. Nilai $\mathrm{pH}$ ini belum sesuai dengan standar minimum SNI kompos matang sebesar 6,8 namun tidak terlalu berbeda jauh. Nilai $\mathrm{pH}$ tertinggi di awal penelitian terdapat pada kompos dengan perlakuan Acticomp (6,6 dan 6,63) yang sudah mendekati $\mathrm{pH}$ tanah untuk keempat limbah, namun di akhir penelitian, nilai pH mengalami perubahan. Kompos pada kontrol menunjukkan kenaikan nilai $\mathrm{pH}$ dan tertinggi dibandingkan perlakuan lainnya untuk keempat limbah $(7,8$ dan 7,73$)$. Nilai ini melebihi dari standar maksimum SNI kompos matang sebesar 7,49 dan jauh dari $\mathrm{pH}$ tanah. Hal ini disebabkan karena pada perlakuan ini tidak mendapat tambahan bioaktivator. Tingginya $\mathrm{pH}$ pada perlakuan ini menyebabkan mikroorganisme yang ada tidak dapat berkembang untuk mencapai pH netral tanah. Hanafiah (2005) menyatakan bahwa umumnya mikroba penghancur berperan dalam proses penguraian bahan organik dan umumnya mikrobia tersebut dapat berkembang dan aktif pada $\mathrm{pH}$ netral-alkalis $(6,5-8,5)$, sedangkan proses mineralisasi dan nitrifikasi optimum pada $\mathrm{pH}$ sekitar 7,0.

Nilai $\mathrm{pH}$ akhir terendah dari keempat perlakuan ditunjukkan oleh kompos dengan perlakuan Acticomp $(7,33)$, nilai ini berada di kisaran nilai $\mathrm{pH}$ standar SNI kompos dan hampir sama dengan $\mathrm{pH}$ tanah. Hal ini berarti pengomposan dengan perlakuan EM-4 dan Acticomp menghasilkan nilai $\mathrm{pH}$ yang bersifat alkalis yang disebabkan oleh salah satu sifat 
bahan organik yang difermentasikan secara aerobik. $\mathrm{pH}$ kompos yang mendekati $\mathrm{pH}$ tanah akan optimum dalam penyediaan unsur hara yang diperlukan oleh tanaman sedangkan pada pH 7 ke atas akan terjadi reduksi bahan kompos menjadi gas amoniak yang tidak menguntungkan untuk pertumbuhan tanaman. Hal ini sesuai dengan pendapat Hanafiah (2005) yang menyatakan $\mathrm{pH}$ optimum untuk ketersediaan unsur hara tanah adalah sekitar 7,0 karena pada $\mathrm{pH}$ ini semua unsur makro tersedia secara maksimum.

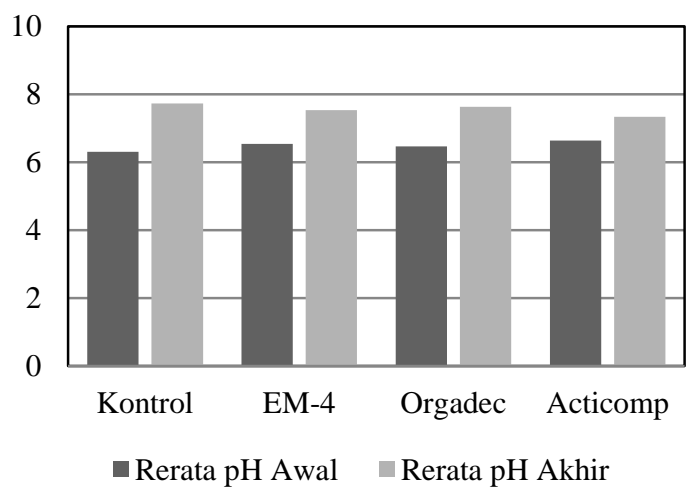

Gambar 6. Rerata Perubahan pH Kompos di Awal dan Akhir Penelitian

\section{KESIMPULAN DAN SARAN}

\section{Kesimpulan}

1. Efektivitas Bioaktivator EM-4, Acticomp dan Orgadec memberikan pengaruh terhadap pembuatan kompos dari limbah sayur dan daun.

2. Bioaktivator Acticomp merupakan bioaktivator terbaik dalam menghasilkan kompos dari limbah sayur dan daun.

\section{Saran}

Perlu diketahui unsur Kalium dan Phospor pada kompos dan uji tanam untuk melihat pertumbuhan dan perkembangan tanaman setelah pemberian kompos.

\section{DAFTAR PUSTAKA}

Anif, S dan D. Astuti. 2008. Efektivitas EM-4 (Effective Microorganisms-4) dalam Menurunkan BOD (Biological Oxygen Demand) Limbah Alkohol. Jurnal Sains dan Teknologi. 4(2): 101-114.

Astari, L. P. 2011. Kualitas Pupuk Kompos Bedding Kuda dengan Menggunakan
Aktivator Mikroba yang Berbeda. Skripsi Fakultas Peternakan Institut Pertanian Bogor, Bogor (Tidak Dipublikasikan).

BPBPI. 2007. Acticomp. Online pada: http://www.ibriec.org. Diakses paada Tanggal 14 Okto-ber 2014.

. 2009. Orgadec. Online pada: http://www.ibriec.org. Diakses pada Tanggal 14 Oktober 2013.

Buckman, H. O. and N. C. Brady. 1982. Ilmu Tanah. Bhratara Karya Aksara, Jakarta.

Dalzell, H. W., A. J. Biddlestone, K. R. Gray and K. Thurairajah. 1987. Soil Management: Compost Production and Use in Tropical and Subtropical Environment. Soil Bulletin 56, UN FAO. Roma.

Hanafiah, K. A. 2005. Dasar-dasar Ilmu Tanah. Raja Garfindo Persada, Jakarta.

Isroi. 2008. Kompos. Makalah Disampaikan pada Acara Study Research Siswa SMU Negeri 81 Jakarta. 1-2 Februari 2008. BPBPI, Bogor.

Makarim, A. K., Sumarno dan Suyanto. 2007. Jerami Padi Pengolahan dan Pemanfaatan. BPTP, Jakarta.

Manser. 2008. Cara Membuat Kompos. Online pada: http://petanidesa.wordpress.com. Diakses pada Tanggal 28 April 2014.

Nurullita, U. dan Budiyono. 2012. Lama Waktu Pengomposan Sampah Rumah Tangga berdasarkan Jenis Mikro Organisme Lokal (MOL) dan Teknik Pengomposan. Seminar Hasil-hasil Penelitian LPPM UNIMUS, Semarang.

Pangestuti, M. 2008. Kajian Penambahan Isolat Bakteri Indigenous Sampah Kota Terhadap Kualitas Kompos dari Berbagai Imbangan Seresah Kacang Tanah (Arachis hypogea) dan Jerami Padi (Oryza sativa. L). Skripsi Fakultas Pertanian Universitas Sebelas Maret, Surakarta (Tidak Dipublikasikan).

Standar Nasional Indonesia. 2004. Spesifikasi Kompos dari Sampah Organik Domestik. SNI 19-7030-2004. Badan Standar Nasional, Jakarta.

Sutanto, R. 2002. Penerapan Pertanian Organik. Kanisius. Yogyakarta.

Sutedjo, M. M., A. G. Kartasapoetra, R. D. S. Sastroatmodjo. 1991. Mikrobiologi Tanah. Rineka Cipta, Jakarta.

Syahputra, A. 2009. Produksi Gas Bio dari Campuran Kotoran Sapi Perah dengan 
Kompos Jerami Padi pada Rasio C/N yang Berbeda. Skripsi Fakultas Peternakan Instititut Pertanian Bogor, Bogor (Tidak Dipublikasikan).

Wahyono, S., L. Firman, Sahwan dan F. Suryanto. 2011. Membuat Pupuk Organik Granul dari Aneka Limbah. Agromedia Pustaka, Jakarta. 